\title{
Risk Factors for Wound Infection Following Caesarean Section: A Case Control Study from Sir Salimullah Medical College \& Mitford Hospital in Dhaka, Bangladesh
}

\author{
Farhana Israt Jahan', Ferdousi Begum ${ }^{2}$, Farzana Islam³ ${ }^{3}$, Shahana Pervin", Annekathryn Goodman ${ }^{*}$ \\ ${ }^{1}$ Department of Gynecologic Oncology, National Institute of Cancer Research \& Hospital, Mohakhali, Dhaka, Bangladesh \\ ${ }^{2}$ Department of Obstetrics \& Gynecology, Ibrahim Medical College \& Birdem Hospital, Dhaka, Bangladesh \\ ${ }^{3}$ Railway General Hospital, Komlapur, Dhaka, Bangladesh \\ ${ }^{4}$ Department of Gynecologic Oncology, National Cancer Research Institute Hospital, Mohakhali, Dhaka, Bangladesh \\ ${ }^{5}$ Department of Obstetrics and Gynecology, Massachusetts General Hospital, Boston, Massachusetts, USA \\ Email: drfarjahan@yahoo.com, fbegum9@gmail.com, farzanaruma2000@gmail.com, shahana.pervin@yahoo.com, \\ *agoodman@mgh.harvard.edu
}

How to cite this paper: Jahan, F.I., Begum, F., Islam, F., Pervin, S. and Goodman, A. (2019) Risk Factors for Wound Infection Following Caesarean Section: A Case Control Study from Sir Salimullah Medical College \& Mitford Hospital in Dhaka, Bangladesh. Open Journal of Obstetrics and Gynecology, 9, 904-913.

https://doi.org/10.4236/ojog.2019.96088

Received: May 22, 2019

Accepted: June 25, 2019

Published: June 28, 2019

Copyright $\odot 2019$ by author(s) and Scientific Research Publishing Inc. This work is licensed under the Creative Commons Attribution International License (CC BY 4.0).

http://creativecommons.org/licenses/by/4.0/

Open Access

\begin{abstract}
Background: Post caesarean section (CS) wound infection or surgical site infection is a leading cause of prolonged hospital stay or readmission. An understanding of its risk factors is important. Methods: A case control study was conducted in the Department of Obstetrics and Gynecology of Sir Salimullah Medical College \& Mitford Hospital, in Dhaka, Bangladesh from January to June 2014 to evaluate the risk factors of postoperative surgical site infection following CS. One hundred patients were studied. Results: Fifty patients of post CS wound infection (surgical site infection: SSI) were selected as cases. Body mass index $>25\left(\mathrm{~kg} / \mathrm{m}^{2}\right)$, anemia $(\mathrm{p}=0.001)$, prolonged rupture of membrane $(p=0.005)$, prolonged operation time $(p=0.019)$, and junior surgeons performing the operation $(\mathrm{p}=0.011)$ were the risk factors for CS-SSI. Conclusions: Pre- and postoperative care and surgical training of junior doctors should be directed to these risk factors.
\end{abstract}

\section{Keywords}

Caesarean Section, Body Mass Index, Wound Infection, Surgical Site Infection, Prolonged Rupture of Membrane

\section{Introduction}

Caesarean section (CS) is a common operation in obstetrics. An analysis of 
health and demographic surveys of seventy-two low and middle income countries (LMICs) conducted between 2010 and 2014 showed national CS rates ranging from $0.6 \%$ in South Sudan to $58.9 \%$ in the Dominican Republic [1]. In Bangladesh, the CS rate increased from $3 \%$ in 2000 to $24 \%$ in 2014 [2]. CS is associated with an increased risk of maternal mortality. A meta-analysis of 196 studies from sixty-seven LMICs evaluated the risk of maternal death in women with CS [3]: 25\% all women who died in LMICs had undergone CS.

CS wound infection (CS-surgical site infection (SSI): CS-SSI) is a major cause of prolonged hospital stay, high hospital cost, increased morbidity and mortality [3] [4] [5]. Best practices including antibiotic prophylaxis, vaginal preparation, and spontaneous placental removal have been recommended as an infection control [6]. Although the incidence CS-SSIs reported to range from $2 \%-7 \%$ in high-income countries [7], it is not well known in low and middle-income countries [8]. Generally speaking, risk factors for CS-SSIs have been reported to include body mass index (BMI) more than 25, anemia, prolonged operative time, premature rupture of membranes (PROM), emergency procedure, pre-existing medical illness, and procedures performed by junior surgeons [9].

While SSIs most commonly manifest between the fifth to eight post-operative days, some SSIs may manifest as early as the third postoperative day depending on the type of bacterial infection [10] [11]. CS-SSI is diagnosed by documenting the typical clinical signs of inflammation, redness, pain and discharge of purulent material [12]. The purpose of this study was to identify the risk factors of CS-SSI in Bangladesh.

\section{Materials and Methods}

A case control study was done in the Department of Obstetrics and Gynecology, Sir Salimullah Medical College \& Mitford Hospital, Dhaka, Bangladesh. Ethical approval was obtained from the Ethics Committee of this institute. One hundred patients who underwent low transverse CS were included. Average postoperative stay after CS was ten days. Patients were excluded if they had undergone CS through a midline sub-umbilical vertical incision. All patients had received preoperative antibiotics, a vaginal preparation, and appropriate surgical aseptic technique. Preoperative antibiotics included one dose of a cephalosporin prior to the skin incision. Surgical aseptic technique followed standard, established guidelines [13]. The vaginal preparation was made with a betadine swab of the vagina.

Patient records from January to June 2014 were reviewed and data was entered into a preapproved questionnaire that listed outcome variables. Outcome variables included BMI, diabetes mellitus, anemia, gestational age, urgency of operation, preoperative hospital stay, duration of operation, and the type of surgeon. All data was directly entered into the computer by using the SPSS/PC software. SSI diagnoses were based on physicians' diagnosis retrieved from the medical charts. SSI were defined as superficial incisional infections affecting skin 
and subcutaneous tissues based on the following signs: redness, pain, heat, swelling at the incisional site, or drainage of pus [14].

\section{Results}

Of 100 patients, 50 and $50 \mathrm{did}$ and did not have CS-SSI. As Table 1 shows, the mean age was $26.5 \pm 6.9$ and $25.15 \pm 3.69$ years in SSI $(+)$ vs. $(-)$ patients, respectively, without significance. Of 50 SSI (+) vs. (-) patients, 30 and 18\%, respectively, had no formal education. Socioeconomic status (SES) did not differ between the two groups.

Table 2 tabulates the BMI of the fifty patients who developed SSIs compared to the fifty patients who did not. The mean BMI was found $34.3 \pm 2.72\left(\mathrm{~kg} / \mathrm{m}^{2}\right)$ in case group and $31.2 \pm 3.5\left(\mathrm{~kg} / \mathrm{m}^{2}\right)$ in control group. The difference of mean BMI was statistically significant $(\mathrm{p}>0.001)$.

Table 3 compares SSI outcomes by the co-morbidities of anemia and diabetes. Diabetes mellitus was found in six (12.0\%) of the case group and five $(10.0 \%)$ of the control group and the difference was not statistically significant $(\mathrm{p}>0.05)$. Anemia, in contrast was statistically significantly different $(\mathrm{p}=0.001)$ between the two groups with $72 \%$ of the cases compared to $42 \%$ of the controls having anemia.

Table 4 examines the differences between the two groups by gravidity and parity. The difference was not statistically significant $(p=0.334)$ between two groups.

Other obstetrical variables evaluated by group in Table 5. Prolonged rupture

Table 1. Demographic variable of patients undergoing caesarean section.

\begin{tabular}{|c|c|c|c|c|c|}
\hline \multirow{2}{*}{$\begin{array}{c}\text { Variables } \\
\text { Age }\end{array}$} & \multicolumn{2}{|c|}{$\begin{array}{l}\text { Postop wound infection } \\
\qquad(\mathrm{n}=50)\end{array}$} & \multicolumn{2}{|c|}{$\begin{array}{l}\text { No infection } \\
\quad(\mathrm{n}=50)\end{array}$} & \multirow[t]{2}{*}{${ }^{*} \mathrm{P}$ value } \\
\hline & No & $\%$ & No & $\%$ & \\
\hline$<19$ & 8 & 16.0 & 4 & 8.0 & \\
\hline $20-24$ & 7 & 14.0 & 11 & 22.0 & \\
\hline $25-29$ & 20 & 40.0 & 15 & 30.0 & $P=0.225$ \\
\hline $30-34$ & 8 & 16.0 & 12 & 24.0 & \\
\hline$>35$ & 7 & 14.0 & 8 & 16.0 & \\
\hline Mean \pm SD & $26.5 \pm 6.9$ & & $25.15 \pm 3.69$ & & \\
\hline \multicolumn{6}{|l|}{ Education } \\
\hline No formal education & 15 & 30.0 & 9 & 18.0 & \\
\hline Primary & 28 & 56.0 & 25 & 50.0 & \\
\hline Secondary & 7 & 14.0 & 16 & 32.0 & \\
\hline \multicolumn{6}{|l|}{ Socioeconomic status } \\
\hline Lower class & 41 & 82 & 37 & 74 & \\
\hline Lower middle class & 9 & 18 & 13 & 16 & \\
\hline
\end{tabular}


Table 2. Distribution of the study patients undergoing caesarean section by Body Mass Index (BMI).

\begin{tabular}{|c|c|c|c|c|c|}
\hline \multirow[t]{2}{*}{ BMI $\left(\mathrm{kg} / \mathrm{m}^{2}\right)$} & \multicolumn{2}{|c|}{$\begin{array}{l}\text { Postop wound infection } \\
\qquad(\mathrm{n}=50)\end{array}$} & \multicolumn{2}{|c|}{$\begin{array}{l}\text { No infection } \\
\quad(n=50)\end{array}$} & \multirow[t]{2}{*}{${ }^{*} \mathrm{P}$ value } \\
\hline & No & $\%$ & No & $\%$ & \\
\hline $19-24$ & 12 & 24.0 & 19 & 38.0 & \\
\hline $25-29$ & 27 & 54.0 & 21 & 42.0 & \\
\hline $30-40$ & 11 & 22.0 & 10 & 20.0 & \\
\hline Mean \pm SD & \multicolumn{2}{|c|}{$34.3 \pm 2.72$} & \multicolumn{2}{|c|}{$31.2 \pm 3.5$} & $\mathrm{P}=0.001$ \\
\hline Range (min, max) & \multicolumn{2}{|c|}{$19-40$} & \multicolumn{2}{|c|}{$(19-38)$} & \\
\hline
\end{tabular}

Table 3. Distribution of the study patients undergoing caesarean section by anemia and diabetes mellitus.

\begin{tabular}{cccccc}
\hline Anemia and diabetes mellitus & $\begin{array}{c}\text { Postop wound infection } \\
(\mathbf{n}=\mathbf{5 0})\end{array}$ & $\begin{array}{c}\text { No Infection } \\
(\mathbf{n}=\mathbf{5 0})\end{array}$ & *P value \\
\hline & No & $\%$ & No & $\%$ & \\
\hline Anemia & & & & & \\
Yes & 37 & 74.0 & 21 & 42.0 & $\mathrm{P}=0.001$ \\
No & 13 & 26.0 & 29 & 58.0 & \\
Diabetes mellitus & & & & & \\
Yes & 6 & 12.0 & 5 & 10.0 & \\
No & 44 & 88.0 & 45 & 90.0 & $\mathrm{P}=0.749$ \\
\hline
\end{tabular}

Table 4. Distribution of the study patients undergoing caesarean section by gravida.

\begin{tabular}{cccccc}
\hline Number of pregnancies & $\begin{array}{c}\text { Postop wound infection } \\
(\mathbf{n}=\mathbf{5 0})\end{array}$ & \multicolumn{2}{c}{$\begin{array}{c}\text { No infection } \\
(\mathbf{n}=\mathbf{5 0})\end{array}$} & $*$ P value \\
\hline No & $\%$ & No & $\%$ & \\
\hline Primiparous & 37 & 74.0 & 41 & 82.0 & $\mathrm{P}=0.334$ \\
Multiparous & 13 & 26.0 & 9 & 18.0 & \\
\hline
\end{tabular}

Table 5. Distribution of the study patients undergoing caesarean section by obstetrics-related variables.

\begin{tabular}{cccccc}
\hline Obstetrics-related variables & $\begin{array}{c}\text { Postop wound infection } \\
(\mathrm{n}=50)\end{array}$ & $\begin{array}{c}\text { No infection } \\
(\mathrm{n}=50)\end{array}$ & *P value \\
\hline & No & $\%$ & No & $\%$ & \\
\hline Prolonged rupture of membrane & 13 & 26.0 & 8 & 16.0 & $\mathrm{P}=0.005$ \\
Presence of preeclampsia & 10 & 20.0 & 3 & 6.0 & $\mathrm{P}=0.037$ \\
Presence of meconium & 3 & 6.0 & 2 & 4.0 & $\mathrm{P}=0.338$ \\
\hline
\end{tabular}

of membrane was found $13(26.0 \%)$ in the case group and 8 (16.0\%) in the control group. The difference was statistically significant $(\mathrm{p}=0.005)$. Preeclampsia 
was present in ten $(20.0 \%)$ women with SSIs versus three $(6.0 \%)$ women without SSIs. The difference was statistically significant $(\mathrm{p}=0.037)$.

Table 6 evaluates the difference in SSIs by indications for surgery. Emergency Caesarean section was done $40(80.0 \%)$ of patients who developed SSIs compared to $30(60.0 \%)$ who did not. Routine Caesarean section was done $10(20.0 \%)$ of patients in the case group and $20(40.0 \%)$ in the control group. The difference was statistically significant $(\mathrm{p}=0.005)$.

Table 7 documents the length of time from admission to Caesarean section. The mean duration of time between hospital admission and operation was 10.3 \pm 6.5 hours in the case group and $7.10 \pm 3.7$ hours in the control group. The difference was statistically significant $(\mathrm{p}=0.003)$.

Table 8 documents surgical times. Operation time was less than one hour for $28(56 \%)$ of patients in the case group and $39(78.0 \%)$ in the control group whereas $22(44 \%)$ patients in case group and $11(22 \%)$ patients in control group had operative times greater than one hour. The difference was statistically significant $(\mathrm{p}=0.019)$.

The final table, Table 9, looks at SSI rates by the experience of the surgeon. Junior surgeons performed operations for 35 (70\%) of patients who developed

Table 6. Distribution of the study patients undergoing caesarean section by urgency of operation.

\begin{tabular}{cccccc}
\hline Urgency of operation & $\begin{array}{c}\text { Postop wound infection } \\
(\mathrm{n}=\mathbf{5 0})\end{array}$ & \multicolumn{2}{c}{$\begin{array}{c}\text { No Infection } \\
(\mathrm{n}=\mathbf{5 0})\end{array}$} & *P value \\
\hline & No & $\%$ & No & $\%$ & \\
\hline Emergency Caesarean section & 40 & 80.0 & 30 & 60.0 & $\mathrm{P}=0.005$ \\
Routine Caesarean section & 10 & 20 & 20 & 40 & \\
\hline
\end{tabular}

Table 7. Distribution of the study patients undergoing caesarean section by duration of time between hospital admission and operation.

\begin{tabular}{cccccc}
\hline $\begin{array}{c}\text { Duration of time between hospital } \\
\text { admission \& operation }\end{array}$ & $\begin{array}{c}\text { Postop wound infection } \\
(\mathrm{n}=50)\end{array}$ & $\begin{array}{c}\text { No infection } \\
(\mathrm{n}=50)\end{array}$ & $*$ * value \\
\hline & No & $\%$ & No & $\%$ & \\
\hline$<6 \mathrm{hrs}$ & 13 & 26.0 & 25 & 50.0 & \\
$6-12 \mathrm{hrs}$ & 22 & 44.0 & 21 & 42.0 & \\
$>12 \mathrm{hrs}$ & 15 & 30.0 & 4 & 8.0 & \\
Mean $\pm \mathrm{SD}$ & \multicolumn{2}{c}{$10.3 \pm 6.5$} & $7.10 \pm 3.7$ & $\mathrm{P}=0.003$ \\
\hline
\end{tabular}

Table 8. Distribution of the study patients by duration of operation.

\begin{tabular}{cccccc}
\hline Duration of operation $(\mathrm{hr})$ & $\begin{array}{c}\text { Postop wound infection } \\
(\mathrm{n}=\mathbf{5 0 )}\end{array}$ & \multicolumn{2}{c}{$\begin{array}{c}\text { No Infection } \\
(\mathbf{n}=\mathbf{5 0})\end{array}$} & *P value \\
\hline & No & $\%$ & No & $\%$ & \\
\hline$<1 \mathrm{hr}$ & 28 & 56.0 & 39 & 78.0 & $\mathrm{P}=0.019$ \\
$>1 \mathrm{hr}$ & 22 & 44.0 & 11 & 22.0 & \\
\hline
\end{tabular}


Table 9. Distribution of the study patients undergoing caesarean section by experience of the Surgeon.

\begin{tabular}{cccccc}
\hline Surgeon & $\begin{array}{c}\text { Postop wound infection } \\
(\mathrm{n}=5 \mathbf{5})\end{array}$ & \multicolumn{2}{c}{$\begin{array}{c}\text { On Infection } \\
(\mathrm{n}=5 \mathbf{5})\end{array}$} & *P value \\
\hline & No & $\%$ & No & $\%$ & \\
\hline Junior Surgeon/Registrar & 35 & 70.0 & 37 & 74.0 & $\mathrm{P}=0.011$ \\
Senior Surgeon/Consultant & 15 & 30.0 & 13 & 26.0 & \\
\hline
\end{tabular}

SSIs whereas for senior surgeons, SSIs developed in 15 (30\%) of patients. The difference was statistically significant $(\mathrm{p}=0.011)$.

\section{Discussion}

We here demonstrated CS-SSI risk factors in Bangladesh. There have been very few published data on this topic in Bangladesh. A study from Bangabandhu Sheikh Mujib Medical University (BSMMU) in Dhaka, a large postgraduate hospital reported on SSIs following general surgical cases [15]. There was a $20 \%$ wound infection rate among 496 elective general surgical procedures. SSIs increased with degree of contamination and increasing operative time. The common risk factors were anemia (52\%), malnutrition (44\%), diabetes (38\%), jaundice $(30 \%)$, contaminated operation (44\%), dirty operation (38\%), obesity and smoking. In another tertiary care hospital in Bangladesh, overall prevalence rate of SSI was $14 \%$ and that the 3 most common pathogens isolated were Staphylococcus aureus (41.9\%); Escherichia coli (30.8\%); and Enterococcus spp. (12\%) [16]. There are no published reports from Bangladesh that have specifically examined CS-SSI rates. One report of 124 eclamptic patients with CS showed a morbidity rate, which included infections of 53\% [17].

There are well known interventions to reduce SSIs including good surgical tissue handling and aseptic technique [18] [19]. The use of prophylactic antibiotics in women undergoing CS reduced SSI, endometritis and serious infectious [20]. This leads us to believe that prophylactic antibiotics may reduce the CS-SSI rate in this area. Other risk reduction interventions include vaginal cleansing with sponge stick preparation of povidone-iodine $10 \%$ for at least 30 seconds immediately before CS: this actually reduced the risk of postoperative endometritis [21] [22]. A meta-analysis of six randomized controlled trials and three cohort showed that in high-risk obese women prophylactic negative pressure wound therapy reduced CS-SSI [23].

The incidence of CS has dramatically increased in Bangladesh [2]. With this increase, increased risk of infections and long-term morbidity and mortality have become concerns. In a study of 500 consecutive patients with CS, there was $24 \%$ SSI [24]. Risk factors for SSIs included PROM, antibiotics given earlier than two hours before the procedure, and increased length of hospital stay [24].

In our study, of 100 patients, 70 underwent emergent CS. Emergency Caesarean sections increase the risk of SSI as compared to elective surgery [11] [12] 
[25]. In this study, the mean age was similar between women with SSI (+) vs. $(-)$, which accorded with the previous data [26]. Also, we re-confirmed that high BMI increased the rate of CS-SSI, similar findings with the previous report [12] [27]. Patients with anemia were more prone to CS-SSIs. Anemia diminishes resistance to infection and is frequently associated with puerperal sepsis. Preoperative anemia is an important predictor of infection [28] [29].

Patients with preexisting illnesses like diabetes mellitus, or malnutrition were more prone to infection. Hypertension, preexisting or pregnancy induced, and other co-morbid states have been associated with SSI [30]. We did not find a significant difference in SSIs between our patients with or without diabetes mellitus.

PROM was a significant risk for SSI. In the present study, $44 \%$ and $42 \%$ of the case and control patients, respectively, underwent CS within 6 - 12 hours after admission. In contrast, $26 \%$ and $50 \%$ of case and control patients underwent CS in less than $6 \mathrm{hrs}$ after hospitalization. A significant correlation was found between the duration of preoperative hospital stay and development of SSI. Previous studies also found a similar association of delay in surgery with SSIs [5] [31] [32]. We found the highest incidence of SSI on the seventh postoperative day, being consistent with other studies [27].

Operations performed by junior surgeons had statistically significantly higher risk of SSI compared to senior surgeons. Other studies have found an association between surgical experience and risk of SSI [33] [34].

This study was the first report to analyze risk factors for CS-SSIs in Bangladesh. The strength of this study was a cohort study in a single institution. The limitation of this study was its retrospective nature, which could introduce selection bias. A cross-section of patients undergoing CS was analyzed and this population may not represent all CS-patients. There is an urgent need for the development of a complete booking/registration system.

\section{Conclusion}

This study demonstrated CS-SSI risk factors in Bangladesh. Identified risk factors included increased body weight, diabetes, anemia, PROM, and surgeries performed by junior surgeons. The data were fundamentally similar to data from other countries. The use of evidence-based risk reducing interventions as reported by others will improve outcomes [35].

\section{Conflicts of Interest}

The authors have no conflicts of interest.

\section{References}

[1] Boatin, A.A., Schlotheuber, A., Betran, A.P., Moller, A.B., Barros, A.J.D., Boerma, T., Torloni, M.R., Victora, C.G. and Hosseinpoor, A.R. (2018) Within Country Inequalities in Caesarean Section Rates: Observational Study of 72 Low and Middle Income Countries BMJ, 24, k55. https://doi.org/10.1136/bmj.k55 
[2] Rahman, M.M., Haider, M.R., Moinuddin, M., Rahman, A.E., Ahmed, S. and Khan, M.M. (2018) Determinants of Caesarean Section in Bangladesh: Cross-Sectional Analysis of Bangladesh Demographic and Health Survey 2014 Data. PLOS ONE, 13, e0202879. https://doi.org/10.1371/journal.pone.0202879

[3] Sobhy, S., Arroyo-Manzano, D., Murugesu, N., Karthikeyan, G., Kumar, V., Kaur, I., Fernandez, E., Gundabattula, S.R., Betran, A.P., Khan, K., Zamora, J. and Thangaratinam, S. (2019) Maternal and Perinatal Mortality and Complications Associated with Caesarean Section in Low-Income and Middle-Income Countries: A Systematic Review and Meta-Analysis. The Lancet, 393, 1973-1982.

[4] Ezechi, O.C., Fasubaa, O.B. and Dare, F.O. (2000) Socioeconomic Barrier to Safe Motherhood among Patients in Rural Nigerian Communities. Journal of Obstetrics and Gynaecology, 20, 32-34. https://doi.org/10.1080/01443610063426

[5] Onwudiegwu, U., Makinde, O.N., Ezechi, O.C. and Adeyemi, A. (1999) Decision Caesarean Delivery Interval in Nigerian University Teaching Hospital: Implication for Maternal Morbidity and Mortality. Journal of Obstetrics and Gynaecology, 19, 30-33.

[6] Martin, E.K., Beckmann, M.M., Barnsbee, L.N., Halton, K.A., Merollini, K. and Graves, N. (2018) Best Practice Perioperative Strategies and Surgical Techniques for Preventing Caesarean Sectionsurgical Site Infections: A Systematic Review of Reviews and Meta-Analyses. BJOG, 125, 956-964.

https://doi.org/10.1111/1471-0528.15125

[7] Blumenfeld, Y.J., El-Sayed, Y.Y., Lyell, D.J., Nelson, L.M. and Butwick, A.J. (2015) Risk Factors for Prolonged Postpartum Length of Stay Following Cesarean Delivery. American Journal of Perinatology, 32, 825-832. https://doi.org/10.1055/s-0034-1543953

[8] Shahida, S.M., Islam, M.A., Dey, B.R., Islam, F., Venkatesh, K. and Goodman, A. (2016) Hospital Acquired Infections in Low and Middle Income Countries: Root Cause Analysis and the Development of Infection Control Practices in Bangladesh. Open Journal of Obstetrics and Gynecology, 6, 28-39. https://doi.org/10.4236/ojog.2016.61004

[9] Poggi, S.B.H. (2013) Post Partum Hemorrhage \& the Abnormal Puerperium. Chapter 21 .

[10] Dallolio, L., Raggi, A., Sanna, T., Mazzetti, M., Orsi, A., Zanni, A., Leoni, E., et al. (2017) Surveillance of Environmental and Procedural Measures of Infection Control in the Operating Theatre Setting. International Journal of Environmental Research and Public Health, 15, 46. https://doi.org/10.3390/ijerph15010046

[11] Shukla, Y.P., Dubey, R., Gupta, A. and Datta, C. (2017) Clinicopathological and Bacteriological Profile of Surgical Site Infections in Emergency Laparotomies. National Journal of Medical and Dental Research, 6, 318-323.

[12] Kamat, U., Ferreira, A., Savio, R. and Motghare, D. (2008) Antimicrobial Resistance among Nosocomial Isolates in a Teaching Hospital in Goa. Indian Journal of Community Medicine, 33, 89-92. https://doi.org/10.4103/0970-0218.40875

[13] Alberta Health Services (2012) Surgical Aseptic Technique and Sterile Field: Guideline for Asepsis for Invasive Surgical Procedures Conducted in Community-Based Healthcare Settings.

https://www.albertahealthservices.ca/assets/wf/eph/wf-eh-surgical-aseptic-techniqu e-sterile-field.pdf

[14] CDC Centers for Disease Control and Prevention (2018) NHSN Surgical Site Infection Surveillance in 2018. https://www.cdc.gov/nhsn/pdfs/training/2018/ssi-508.pdf 
[15] Nur-e-elahi, M., Jahan, I., Siddiqui, O., Ahmed, S., Joarder, A., Faruque, S., Imdad, S., Ahmed, H., Islam, M., Siddiqui, M. and Sardar, K. (2014) Wound Infection in Surgery Department in BSMMU: A Study of 100 Cases. Journal of the Bangladesh Society of Anaesthesiologists, 24, 65-69. https://doi.org/10.3329/jbsa.v24i2.19804

[16] Sickder, H.K., Lertwathanawilat, W., Sethabouppha, H. and Viseskul, N. (2017) Prevalence of Surgical Site Infection in a Tertiary-Level Hospital in Bangladesh. International Journal of Natural and Social Sciences, 4, 63-68.

[17] Parna, F.H., Latif, T., Sultana, N., et al. (2013) Maternal \& Fetal Outcome of Eclamptic Patients Admitted in Obstetrics \& Gynaecology Department of Secondary Care Hospital in Bangladesh. Mymensingh Medical Journal, 22, 522-526.

[18] Hadiati, D.R., Hakimi, M., Nurdiati, D.S., da Silva Lopes, K. and Ota, E. (2018) Skin Preparation for Preventing Infection Following Caesarean Section. Cochrane Database Systematic Reviews, No. 10, CD007462. https://doi.org/10.1002/14651858.CD007462.pub4

[19] Springel, E.H., Wang, X.Y., Sarfoh, V.M., Stetzer, B.P., Weight, S.A. and Mercer, B.M. (2017) A Randomized Open-Label Controlled Trial of Chlorhexidine-Alcohol vs. Povidone-Iodine for Cesarean Antisepsis: The CAPICA Trial. American Journal of Obstetrics \& Gynecology, 217, 463.e1-463.e8. https://doi.org/10.1016/j.ajog.2017.05.060

[20] Smaill, F.M. and Grivell, R.M. (2014) Antibiotic Prophylaxis versus No Prophylaxis for Preventing Infection after Cesarean Section. Cochrane Database Systematic Review, No. 10, CD007482. https://doi.org/10.1002/14651858.CD007482.pub3

[21] Caissutti, C., Saccone, G., Zullo, F., Quist-Nelson, J., Felder, L., Ciardulli, A. and Berghella, V. (2017) Vaginal Cleansing before Cesarean Delivery: A Systematic Review and Meta-Analysis. Obstetrics \& Gynecology, 130, 527-538. https://doi.org/10.1097/AOG.0000000000002167

[22] Haas, D.M., Morgan, S., Contreras, K. and Enders, S. (2018) Vaginal Preparation with Antiseptic Solution before Cesarean Section for Preventing Postoperative Infections. Cochrane Database Systematic Reviews, No. 7, CD007892. https://doi.org/10.1002/14651858.CD007892.pub6

[23] Yu, L., Kronen, R.J., Simon, L.E., Stoll, C., Colditz, G.A. and Tuuli, M.G. (2017) Prophylactic Negative-Pressure Wound Therapy after Cesarean Is Associated with Reduced Risk of Surgical Site Infection: A Systematic Review and Meta-Analysis. American Journal of Obstetrics and Gynecology, 218, 200-210.e1. https://doi.org/10.1016/j.ajog.2017.09.017

[24] De, D., Saxena, S., Mehta, G., Yadav, R. and Dutta, R. (2013) Risk Factor Analysis and Microbial Etiology of Surgical Site Infections Following Lower Segment Caesarean Sections. International Journal of Antibiotics, 2013, Article ID: 283025. https://doi.org/10.1155/2013/283025

[25] Cantürk, Z., Cantürk, N.Z., Cetinarslan, B., Utkan, N.Z. and Tarkun, I. (2003) Nosocomial Infections and Obesity in Surgical Patients. Obesity Research, 11, 769-775. https://doi.org/10.1038/oby.2003.107

[26] Rahman, J., Sultana, N., Hasan, M. and Begum, H.A. (2011) Factors of Post-Operative Wound Infection in Abdominal Surgeries of Obstetrics and Gynaecology Department. Journal Dhaka National Medical College Hospital, 18, 39-42. https://doi.org/10.3329/jdnmch.v18i1.12239

[27] Moir-Bussy, B.R., Hutton, R.M. and Thompson, J.R. (1984) Wound Infection after Caesarean Section. Journal of Hospital Infection, 5, 359-370. https://doi.org/10.1016/0195-6701(84)90003-3 
[28] Waisbern, E., Rosen, H., Badar, A.M., Lipsitz, S.R., Rogers, S.O. and Eriksson, E. (2010) Percent of Body Fat and Prediction of Surgical Site Infection. Journal of American College of Surgeons, 210, 381-389. https://doi.org/10.1016/j.jamcollsurg.2010.01.004

[29] Walter, P., Zwahlen, M., Reck, S., Misteli, H., Rosenthal, R., Buser, A.S., Kaufmann, M., Oertli, D., Widmer, A.F. and Marti, W.R. (2009) The Association of Preoperative Anemia and Perioperative Allogeneic Blood Transfusion with the Risk of Surgical Site Infection. Transfusion, 49, 1964-1970. https://doi.org/10.1111/j.1537-2995.2009.02204.x

[30] Pierson, R.C., Scott, N.P., Briscoe, K.E. and Haas, D.M. (2018) A Review of Post-Caesarean Infectious Morbidity: How to Prevent and Treat. Journal of Obstetrics \& Gynaecology, 38, 591-597. https://doi.org/10.1080/01443615.2017.1394281

[31] Lilani, S.P., Jangale, N., Chowdhary, A. and Daver, G.B. (2005) Surgical Site Infection in Clean AND Clean-Contaminated Cases. Indian Journal of Medical Microbiology, 23, 249-252.

[32] Ward, V.P., Charlett, A., Fagan, J. and Crawshaw, S.C. (2008) Enhanced Surgical Site Infection Surveillance Following Caesarean Section: Experience of a Multicentre Collaborative Post-Discharge System. Journal of Hospital Infection, 70, 166-173. https://doi.org/10.1016/j.jhin.2008.06.002

[33] Hassan, K.O. and Alegbeleye, J.O. (2018) Post Caesarean Section Wound Infection and Microbiological Pattern at the University of Port Harcourt Teaching Hospital, Southern Nigeria. Research in Obstetrics and Gynecology, 6, 1-8.

[34] Makinde, O.O. (1987) A Review of Caesarean Section at the University of Ife Teaching Hospitals. Tropical Journal of Obstetrics and Gynaecology, 6, 26-30.

[35] Kawakita, T. and Landy, H.J. (2017) Surgical Site Infections after Cesarean Delivery: Epidemiology, Prevention and Treatment. Maternal Health, Neonatology and Perinatology, 3, 12. https://doi.org/10.1186/s40748-017-0051-3 